Supplement of Nat. Hazards Earth Syst. Sci. Discuss., 2, 6555-6597, 2014

http://www.nat-hazards-earth-syst-sci-discuss.net/2/6555/2014/

doi:10.5194/nhessd-2-6555-2014-supplement

(c) Author(s) 2014. CC Attribution 3.0 License.

(c) (i)

Natural Hazards and Earth System Sciences

Discussions

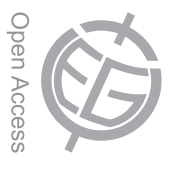

Supplement of

\title{
Development of a global fire weather database for 1980-2012
}

R. D. Field et al.

Correspondence to: R. D. Field (rf2426@columbia.edu) 
The data can be accessed by ftp from the NASA Center for Climate Simulation Dataportal:

ftp to dataportal.nccs.nasa.gov

user: GlobalFWI

password: <leave this empty>

The current version is v1.3. 